\title{
Decreased light availability can amplify negative impacts of ocean acidification on calcifying coral reef organisms
}

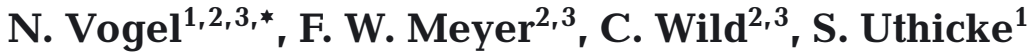 \\ ${ }^{1}$ Australian Institute of Marine Science, PMB 3, Townsville MC, 4810 Queensland, Australia \\ ${ }^{2}$ Leibniz Center for Tropical Marine Ecology, Fahrenheitstraße 6, 28359 Bremen, Germany \\ ${ }^{3}$ Faculty of Biology and Chemistry (FB 2), University of Bremen, 28359 Bremen, Germany
}

\begin{abstract}
Coral reef organisms are increasingly and simultaneously affected by global and local stressors such as ocean acidification $(\mathrm{OA})$ and reduced light availability. However, knowledge of the interplay between OA and light availability is scarce. We exposed 2 calcifying coral reef species (the scleractinian coral Acropora millepora and the green alga Halimeda opuntia) to combinations of ambient and increased $\mathrm{pCO}_{2}$ (427 and $1073 \mu \mathrm{atm}$, respectively), and 2 light intensities (35 and $150 \mu \mathrm{mol}$ photons $\mathrm{m}^{-2} \mathrm{~s}^{-1}$ ) for $16 \mathrm{~d}$. We evaluated the individual and combined effects of these 2 stressors on weight increase, calcification rates, $\mathrm{O}_{2}$ fluxes and chlorophyll a content for the species investigated. Weight increase of $A$. millepora was significantly reduced by OA $(48 \%)$ and low light intensity $(96 \%)$ compared to controls. While OA did not affect coral calcification in the light, it decreased calcification in the dark by $155 \%$, leading to dissolution of the skeleton. H. opuntia weight increase was not affected by OA, but decreased $(40 \%)$ at low light. OA did not affect algae calcification in the light, but decreased calcification in the dark by $164 \%$, leading to dissolution. Low light significantly reduced gross photosynthesis (56 and $57 \%$ ), net photosynthesis (62 and $60 \%$ ) and respiration (43 and $48 \%$ ) of $A$. millepora and $H$. opuntia, respectively. In contrast to A. millepora, $H$. opuntia significantly increased chlorophyll content by $15 \%$ over the course of the experiment. No interactive effects of OA and low light intensity were found on any response variable for either organism. However, A. millepora exhibited additive effects of OA and low light, while $H$. opuntia was only affected by low light. Thus, this study suggests that negative effects of low light and OA are additive on corals, which may have implications for management of river discharge into coastal coral reefs.
\end{abstract}

KEY WORDS: $\mathrm{pH} \cdot$ Turbidity · Calcification · Dissolution · Photosynthesis · Corals · Algae · Acropora millepora $\cdot$ Halimeda opuntia

\section{INTRODUCTION}

Anthropogenically increased carbon dioxide $\left(\mathrm{CO}_{2}\right)$ introduced into the atmosphere is changing the earth's climate. In addition to aggravating the greenhouse effect and thus driving global warming, approximately one-third of the atmospheric $\mathrm{CO}_{2}$ is taken up by the oceans (Bindoff et al. 2007). $\mathrm{CO}_{2}$ which is added to the oceanic carbonate system increases hydrogen ion concentrations and thus

\footnotetext{
${ }^{*}$ Corresponding author: n.vogel@aims.gov.au
}

leads to a reduction of seawater $\mathrm{pH}$ (ocean acidification, OA) (Golubik et al. 1979, Kleypas \& Langdon 2006). Depending on the Representative Concentration Pathways (RCP) followed, atmospheric $\mathrm{CO}_{2}$ is predicted to rise from $\sim 395 \mu$ atm at present (Dlugokencky \& Tans 2014) to between 850 and 1370 patm by the year 2100 (RCP6.0 and RCP8.5, respectively), which is correlated with a further decrease in ocean $\mathrm{pH}$ unless drastic reductions in output and/or an increase in carbon capture are achieved (RCP 2.6

() The authors 2015. Open Access under Creative Commons by Attribution Licence. Use, distribution and reproduction are unrestricted. Authors and original publication must be credited. 
and 4.5) (Moss et al. 2010). In turn, a reduction of $\mathrm{pH}$ leads to a shift in the oceanic carbonate system, which results in a decreased calcium carbonate $\left(\mathrm{CaCO}_{3}\right)$ saturation state $(\Omega)$ of seawater. Recent studies revealed negative effects of decreased $\Omega$ on growth/calcification of a vast range of coral reef organisms, leading to predictions of shifts in community structures, loss of framework builders and loss of coral reef biodiversity under future conditions (Gattuso et al. 1998, Langdon et al. 2000, Orr et al. 2005, Ries et al. 2009, Fabricius et al. 2011, 2014, Uthicke \& Fabricius 2012).

In addition to increasing sea surface temperature (SST) and OA, often local disturbances (such as elevated organic and inorganic nutrients, increased turbidity or decreased salinity) present additional pressures on coral reef organisms at inshore reefs exposed to land-runoff (Bell 1992, Fabricius 2005, 2011, Wooldridge et al. 2006, Uthicke et al. 2011). Water quality is known to affect inshore reef communities, leading to declines in hard coral diversity and increased macroalgae richness (Fabricius et al. 2005, Schaffelke et al. 2005, De'ath \& Fabricius 2010). Decrease in water quality on the Great Barrier Reef (GBR) has been linked to anthropogenic activities associated with land-use, and has been in decline since European settlement (McCulloch et al. 2003, Roff et al. 2013). Predominantly during summer months, an increase in precipitation and hence riverine runoff results in more severe consequences to near-shore reef communities. Combinations of global and local stressors may have additive or synergistic effects and may push organisms closer to tolerance thresholds. For instance, interactive effects of OA and irradiance, OA and eutrophication, ocean warming (OW) and herbicides, or OW and eutrophication have all been shown to have impacts on several coral reef organisms (Langdon \& Atkinson 2005, Chauvin et al. 2011, Negri et al. 2011, Uthicke et al. 2011, Comeau et al. 2014).

For many calcareous reef organisms, photosynthesis is essential for energy supply, calcification and/or survival, either because they are autotrophic primary producers or exhibit mixotrophic carbon acquisition. Scleractinian corals host photosynthetically active dinoflagellates as endosymbionts, which provide important energy to the host (Goreau 1959, Wainwright 1963). Moreover, by fixing $\mathrm{CO}_{2}$ from the environment in the light, they increase cellular, surface and boundary layer $\mathrm{pH}$ levels and therefore facilitate the precipitation of $\mathrm{CaCO}_{3}$ by elevating the aragonite saturation state $\left(\Omega_{\text {ar }}\right)$ (Goreau 1959, Al-Horani et al. 2003). For the calcifying green alga genus Hal- imeda, photosynthesis is important for calcification, since some species do not possess active calcification mechanisms. In fact, in some Halimeda species, calcification is a byproduct of increased intracellular $\mathrm{pH}$ from photosynthesis, which results in abiotic precipitation of aragonite needles (de Beer \& Larkum 2001). By increasing the $\mathrm{pH}$ levels in the environment, photosynthesis may even protect organisms against $\mathrm{OA}$, as long as sufficient light is available (de Beer et al. 2000, Al-Horani et al. 2003).

At reefs susceptible to land-runoff, increased turbidity leads to reduced light availability and therefore decreased photosynthetically available radiation (PAR) for photosynthesizing organisms. While sediment from rivers and dredging activities directly increase turbidity, elevated nutrient levels from agricultural land-runoff increase turbidity indirectly. Inshore eutrophication can enhance the abundance of chlorophyll, phytoplankton and microalgae blooms in the water column (Bell 1992, Devlin \& Schaffelke 2009), which in turn leads to a reduction of PAR. Consequently, reduced PAR due to increased turbidity with increasing OA may have additional negative effects on growth, calcification and other responses of coral reef organisms. As shown in previous studies, calcification and photosynthesis in corals decrease with increasing turbidity (Kendall et al. 1983, 1985) and decreasing light intensity (Marubini et al. 2001, Mass et al. 2007). However, knowledge of the interaction between OA and low light conditions is scarce, even though the interplay between these stressors may be crucial. Local stressors that affect light availability are generally easier to manage than global stressors; therefore, it is important to understand these interactions, as findings from manipulative experiments can be used to take action via environmental management plans aiming to reduce stressors on coral reef organisms. Given that photosynthesis plays a crucial role in calcification, and OA has impacts on calcification of many organisms, it is surprising that the present study is one of the first to investigate this interaction.

The aim of the present study was to investigate the individual and interactive effects of OA and decreased PAR on 2 different coral reef taxa, the scleractinian coral Acropora millepora and the calcifying green alga Halimeda opuntia. A. millepora is common and widespread over tropical coral reefs and contributes to primary productivity, carbonate production and reef development. $H$. opuntia is an important major, fast-growing primary producer, commonly found on tropical coral reefs. Halimeda spp. contribute considerably to carbonate produc- 
tion, sediment formation and play an important role in the benthic community by providing habitat for many invertebrate species (Wefer 1980, Freile et al. 1995, Rees et al. 2007, Fukunaga 2008). Thus, we conducted a laboratory experiment using controlled conditions and determined the response parameters, growth rates (measured by buoyant weight), calcification rates in light and in dark (measured by alkalinity anomaly), $\mathrm{O}_{2}$ fluxes (productivity and respiration) and chlorophyll $a(\mathrm{chl} \mathrm{a})$ content.

\section{MATERIALS AND METHODS}

\section{Specimen collection and preparation}

Colonies of the coral Acropora millepora were collected from an inshore fringing reef next to Pelorus Island (central section of the $\mathrm{GBR}_{i} 18^{\circ} 33.001^{\prime} \mathrm{S}$, $146^{\circ} 29.304^{\prime} \mathrm{E}$ ) between 2 and $4 \mathrm{~m}$ below lowest astronomical tide (LAT). After colonies were fragmented, individual coral nubbins were glued onto stubs and kept at the Australian Institute of Marine Science (AIMS, Townsville) in flow-through (recirculating flow $\sim 1200 \mathrm{l} \mathrm{h}^{-1}$ ) aquaria facilities under plasma light $\left(150 \mu \mathrm{mol}\right.$ photons $\left.\mathrm{m}^{-2} \mathrm{~s}^{-1}\right)$ for $>3 \mathrm{mo}$. Nubbins were transferred into experimental tanks 2 wk prior to the start of experiment to acclimate to experimental control conditions. Specimens of the calcifying green alga Halimeda opuntia were collected from a fringing reef next to Orpheus Island, also an inshore reef in the central section of the GBR $\left(18^{\circ} 36.737^{\prime} \mathrm{S}, 146^{\circ} 29.110^{\prime} \mathrm{E}\right)$ between 0.5 and $1.0 \mathrm{~m}$ below LAT. Alga fragments (each with 50 to 100 phylloids) were acclimated in experimental aquaria under control conditions for $2 \mathrm{wk}$ until the start of the experiment.

Light regimes at the collection site of Acropora millepora were similar to control light conditions in the experiment. Halimeda opuntia was subjected to lower light conditions in the experiment than occurred in the field, due to collection from shallower depths. However, both organisms were acclimated to the same 'control light' conditions for $2 \mathrm{wk}$ before the start of the experiment. Light levels chosen as the control and low light conditions were well within average ranges found between 3 and $6 \mathrm{~m}$ below LAT at midshelf and inshore reefs on the GBR, respectively (Uthicke \& Altenrath 2010). Moreover, light data were collected with light loggers (Odyssey) simultaneously at a mid-shelf location (Rib Reef; $18^{\circ} 28.785^{\prime} \mathrm{S}, 146^{\circ}$ $52.256^{\prime} \mathrm{E}$ ) and an inshore location (Orpheus Island; $18^{\circ} 38.949^{\prime} \mathrm{S}, 146^{\circ} 29.183^{\prime} \mathrm{E}$ ) at $5 \mathrm{~m}$ below LAT over a period of 18 d in February 2013. At Rib Reef, daily light sums averaged $10.45 \mathrm{~mol}$ photons $\mathrm{m}^{-2} \mathrm{~d}^{-1}$, ranging from 4.58 to $13.35 \mathrm{~mol}$ photons $\mathrm{m}^{-2} \mathrm{~d}^{-1}$. Daily light sums at Orpheus Island averaged 1.95 mol photons $\mathrm{m}^{-2} \mathrm{~d}^{-1}$, ranging from 0.22 to $4.66 \mathrm{~mol}$ photons $\mathrm{m}^{-2} \mathrm{~d}^{-1}$. Hence, experimental conditions (daily light sums of $6.48 \mathrm{~mol}$ photons $\mathrm{m}^{-2} \mathrm{~d}^{-1}$ for controls and $1.51 \mathrm{~mol}$ photons $\mathrm{m}^{-2} \mathrm{~d}^{-1}$ for low light regimes) were well within naturally occurring light intensities at $\sim 5 \mathrm{~m}$ below LAT at mid-shelf and inshore locations of the GBR.

\section{Experimental setup}

The manipulative aquaria experiment was carried out in flow-through conditions over a period of $16 \mathrm{~d}$ between July and August 2012 at AIMS. After a $2 \mathrm{wk}$ acclimation period, 4 nubbins of Acropora millepora and 2 fragments of Halimeda opuntia were allocated to each of the 12 experimental aquaria. Four treatments with 3 replicate tanks (working volume $17.5 \mathrm{l}$ ) were placed in alternating order. Treatments consisted of combinations of ambient $\mathrm{pCO}_{2}(427 \mu \mathrm{atm})$, high $\mathrm{pCO}_{2}(1073 \mu \mathrm{atm})$, low light (35 $\mu \mathrm{mol}$ photons $\left.\mathrm{m}^{-2} \mathrm{~s}^{-1}\right)$ and control light $\left(150 \mu \mathrm{mol}\right.$ photons $\left.\mathrm{m}^{-2} \mathrm{~s}^{-1}\right)$. High $\mathrm{pCO}_{2}$ conditions corresponded to projections between the RCP 6.0 and RCP 8.5 scenario for the year 2100 (Moss et al. 2010). Light intensities were chosen from average PAR readings from an inshore and mid-shelf reef at $\sim 5 \mathrm{~m}$ below LAT, present during the summer months. Water flow was provided with fresh filtered $(0.5 \mu \mathrm{m})$ seawater at $25^{\circ} \mathrm{C}$, with a salinity of 34.5 , at a flow rate of $150 \mathrm{ml} \mathrm{min}{ }^{-1}$. Irradiance was delivered by white light LED $(6000 \mathrm{~K}$, Aqua Illumination), covering the full color spectrum. Light levels were set to a $12 \mathrm{~h}: 12 \mathrm{~h}$ light:dark cycle. Additional aquarium pumps (AquarWorld, $250 \mathrm{l} \mathrm{h}^{-1}$ ) were fitted into each tank to ensure water movement. Target $\mathrm{pH}$ levels were achieved by an automatic $\mathrm{CO}_{2}$ injection system (Aqua Medic) controlled by potentiometric $\mathrm{pH}$ sensors, as described in Vogel \& Uthicke (2012).

\section{Carbonate system parameters}

Total alkalinity (TA) was determined by gran titration with a Metrohm 855 robotic titrosampler (Metrohm) using $0.5 \mathrm{M} \mathrm{HCl}$ (see also Uthicke \& Fabricius 2012). Total alkalinity was calculated by non-linear regression fitting between $\mathrm{pH} 3.5$ and 3.0 and was corrected to certified reference material (CRM Batch 106, A. Dickson, Scripps Oceanographic Institute). Seawater $\mathrm{pH}$, temperature and millivolts 
$(\mathrm{mV})$ were measured daily (including early morning and evening measurements to incorporate diurnal fluctuations) with a temperature corrected, handheld $\mathrm{pH}$ meter (WTW, Germany), calibrated on the NIST (National Institute of Standards and Technology, USA) scale. Millivolt and temperature readings were utilized to calculate $\mathrm{pH}$ on a total $\left(\mathrm{pH}_{\text {total }}\right)$ scale. Carbonate system parameters (Table 1) were calculated with CO2calc software (Robbins et al. 2010) utilizing $\mathrm{TA}$ and $\mathrm{pH}_{\text {total }}$ values and $\mathrm{CO}_{2}$ constants from Lueker et al. (2000). Carbonate system parameters were calculated from measurements in each aquarium and 3 sampling events over the course of the experiment. Calculated $\mathrm{pCO}_{2}$ levels yielded averages of $427 \mu \mathrm{atm}$ for controls and $1073 \mu \mathrm{atm}$ for future scenario conditions (Table 1 ). $\Omega_{\text {ar }}$ yielded averages of 3.3 and 1.7 for controls and high $\mathrm{pCO}_{2}$ treatments, respectively.

\section{Growth rates}

Growth of organisms was determined by the buoyant weight technique. Individual specimens were single-weighted (accuracy: $0.1 \mathrm{mg}$, Mettler Toledo) in a custom-built buoyant weight set-up with water jacket and seawater of constant temperature $\left(25^{\circ} \mathrm{C}\right)$ and salinity (34.5 ppt) at the start and at the end of the experiment. Growth of organisms was expressed as daily percentage of change.

\section{Calcification in light and dark, net photosynthesis and respiration}

After $16 \mathrm{~d}$ in experimental conditions, 2 individuals of each species and replicate tank were incubated for $1 \mathrm{~h}$ in the light and thereafter $1 \mathrm{~h}$ in the dark to determine calcification and photosynthetic rates. Light intensity and seawater $\mathrm{pH}$ of incubations corresponded to treatment condition of each organism. One experimental run consisted of 12 parallel incubations in $200 \mathrm{ml}$ incubation chambers, including 2 blanks per treatment. To assure constant water temperature during incubation, chambers were placed into a flow-through water bath at $25^{\circ} \mathrm{C}$. Additionally, magnetic stirrer bars ensured water movement within the incubation chambers.

Calcification rates in light and dark were determined by the alkalinity anomaly technique (Chisholm \& Gattuso 1991). A subsample of $50 \mathrm{ml}$ was pipetted from the incubation seawater and directly titrated for TA on a Metrohm 855 (as described above). $\mathrm{CaCO}_{3}$ precipitation or dissolution in $\mu \mathrm{M} \mathrm{C}$ $\mathrm{h}^{-1}$ was calculated following Gao \& Zheng (2010) and standardized to organism surface area (Acropora millepora) or buoyant weight (Halimeda opuntia). Daily net calcification was calculated by $12 \mathrm{~h}$ of daylight and $12 \mathrm{~h}$ of darkness. We determined surface areas of coral nubbins using the wax-weight method (Veal et al. 2010) and chose buoyant weight as standardization for the algae due to their highly 3-dimensional structures and lowest variability in data.

Net photosynthesis in the light or dark respiration were monitored consecutively during the incubations by 3 Firesting 4-channel oxygen meters (Pyroscience), which were connected to each chamber with fiber optic cables. Gross photosynthesis, net photosynthesis and respiration rates were expressed as $\mathrm{MM} \mathrm{O}_{2} \mathrm{~h}^{-1}$ and standardized to organism surface area (A. millepora) or buoyant weight (H. opuntia).

\section{Pigment content}

Chl a content of algae tissue was determined spectrophotometrically. Organisms were frozen to $-80^{\circ} \mathrm{C}$ after incubations. Similar to the chl a extraction

Table 1. Carbonate system parameters (mean with SD in parentheses) of experimental conditions. TA $=$ total alkalinity, DIC $=$ dissolved inorganic carbon, $\mathrm{pCO}_{2}=$ carbon dioxide partial pressure, $\mathrm{HCO}_{3}{ }^{-}=$bicarbonate, $\mathrm{CO}_{3}{ }^{2-}=$ carbonate, $\Omega_{\mathrm{ar}}=$ aragonite saturation state, $\mathrm{SW}=$ seawater

\begin{tabular}{|c|c|c|c|c|c|c|c|c|c|}
\hline Treatment & $\mathrm{pH}_{\text {total }}$ & $\begin{array}{l}\text { Temp } \\
\left({ }^{\circ} \mathrm{C}\right)\end{array}$ & 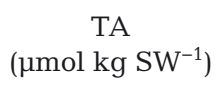 & $\begin{array}{c}\text { DIC } \\
\left.(\mu \mathrm{mol} \mathrm{kg} \mathrm{SW})^{-1}\right)\end{array}$ & $\begin{array}{c}\mathrm{pCO}_{2} \\
(\mu \mathrm{atm})\end{array}$ & $\begin{array}{c}\mathrm{HCO}_{3}^{-} \\
\left(\mu \mathrm{mol} \mathrm{kg} \mathrm{SW}{ }^{-1}\right)\end{array}$ & $\begin{array}{c}\mathrm{CO}_{3}^{2-} \\
\left(\mu \mathrm{mol} \mathrm{kg} \mathrm{SW}{ }^{-1}\right)\end{array}$ & $\begin{array}{c}\mathrm{CO}_{2} \\
\left(\mu \mathrm{mol} \mathrm{kg} \mathrm{SW} W^{-1}\right)\end{array}$ & $\Omega_{\mathrm{ar}}$ \\
\hline $\begin{array}{c}\text { Control } \mathrm{pCO}_{2}+ \\
\text { control light }\end{array}$ & $\begin{array}{c}8.038 \\
(0.031)\end{array}$ & $\begin{array}{l}25.4 \\
(0.2)\end{array}$ & $\begin{array}{c}2276 \\
(13)\end{array}$ & $\begin{array}{l}1990 \\
(17)\end{array}$ & $\begin{array}{l}421 \\
(19)\end{array}$ & $\begin{array}{l}1774 \\
(21)\end{array}$ & $\begin{array}{c}203 \\
(5)\end{array}$ & $\begin{array}{l}12 \\
(1)\end{array}$ & $\begin{array}{c}3.2 \\
(0.1)\end{array}$ \\
\hline $\begin{array}{r}\text { High } \mathrm{pCO}_{2}+ \\
\text { control light }\end{array}$ & $\begin{array}{c}7.707 \\
(0.038)\end{array}$ & $\begin{array}{l}25.3 \\
(0.1)\end{array}$ & $\begin{array}{c}2281 \\
(7)\end{array}$ & $\begin{array}{c}2160 \\
(5)\end{array}$ & $\begin{array}{l}1069 \\
(71)\end{array}$ & $\begin{array}{c}2026 \\
(8)\end{array}$ & $\begin{array}{l}104 \\
(6)\end{array}$ & $\begin{array}{l}30 \\
(2)\end{array}$ & $\begin{array}{r}1.7 \\
(0.1)\end{array}$ \\
\hline $\begin{array}{l}\text { Control } \mathrm{pCO}_{2}+ \\
\text { low light }\end{array}$ & $\begin{array}{c}8.008 \\
(0.015)\end{array}$ & $\begin{array}{l}25.7 \\
(0.8)\end{array}$ & $\begin{array}{c}2278 \\
(7)\end{array}$ & $\begin{array}{l}1983 \\
(11)\end{array}$ & $\begin{array}{l}433 \\
(15)\end{array}$ & $\begin{array}{l}1762 \\
(17)\end{array}$ & $\begin{array}{c}209 \\
(7)\end{array}$ & $\begin{array}{l}12 \\
(1)\end{array}$ & $\begin{array}{c}3.4 \\
(0.1)\end{array}$ \\
\hline $\begin{array}{l}\text { High pCO } \mathrm{pO}_{2}+ \\
\text { low light }\end{array}$ & $\begin{array}{c}7.693 \\
(0.016)\end{array}$ & $\begin{array}{l}25.5 \\
(0.3)\end{array}$ & $\begin{array}{l}2288 \\
(5)\end{array}$ & $\begin{array}{c}2164 \\
(8)\end{array}$ & $\begin{array}{l}1076 \\
(18)\end{array}$ & $\begin{array}{l}2029 \\
(9)\end{array}$ & $\begin{array}{l}106 \\
(2)\end{array}$ & $\begin{array}{l}30 \\
(1)\end{array}$ & $\begin{array}{l}1.7 \\
(0.0)\end{array}$ \\
\hline
\end{tabular}


described in Schmidt et al. (2011) and Vogel \& Uthicke (2012), apical segments of algae were placed in $15 \mathrm{ml}$ Falcon tubes on ice and $4 \mathrm{ml}$ of cold ethanol (95\% EtOH) was added. After crushing the segments with a homogenizer, extracts were heat-shocked in a water bath $\left(78^{\circ} \mathrm{C}\right.$ for $\left.5 \mathrm{~min}\right)$, and left in a fridge for $24 \mathrm{~h}$ extraction. Absorbencies on 750 and $664 \mathrm{~nm}$ were read on a Powerwave microplate reader (BioTek). Chl a content was calculated with equations by Nusch (1980) and standardized to segment fresh weight.

Chl a content of coral Acropora millepora was determined after coral tissue was stripped from the skeleton with an air gun utilizing fresh, ultra-filtered $(0.2 \mu \mathrm{m})$ seawater. Zooxanthellae were isolated from the host tissue and re-suspended in $2 \mathrm{ml}$ of ethanol (EtOH $95 \%$ ), heat-shocked and extracted for $24 \mathrm{~h}$ in the cold. Absorbencies were read (as described above) and $\mathrm{chl} a$ contents were calculated standardized to nubbin surface area.

\section{Statistical analysis}

We statistically tested growth rates, net-, light- and dark-calcification rates, gross photosynthesis, net photosynthesis, respiration, and chl a content for significant differences between experimental treatment conditions. Levene's tests for equal variances were performed on datasets in the software program $\mathrm{R}$ ( $R$ Development Core Team 2014). If necessary, response variables were $\log _{10}$ transformed prior to analyses to fulfill assumptions of equal of variances. Mixed effect ANOVAs were conducted on datasets with NCSS software (Hintze 2007) with pH and light treatment as fixed factors. Replicate tanks were considered as nested (random) factor. To distinguish significantly differing groups we conducted TukeyKramer multiple comparison tests.

\section{RESULTS}

The interaction between $\mathrm{pCO}_{2}$ and light intensity was not significant for any treatment parameter (Table 2). However, the coral Acropora millepora exhibited additive negative effects of high $\mathrm{pCO}_{2}$ and low light conditions on growth rates and calcification rates in the dark (Table 3).

Mean growth rates (Fig. 1) of Acropora millepora were significantly $(\mathrm{p}=0.032)$ reduced in high $\mathrm{pCO}_{2}$ (Tables $2 \& 3$ ) by $48 \%$ compared to controls, while the growth rate of Halimeda opuntia was not im-
Table 2. Mixed effect ANOVA results for the effect of different $\mathrm{pCO}_{2}$ and light conditions on growth rates; net, light, and dark calcification; gross and net photosynthesis; respiration; and chlorophyll a content in the coral Acropora millepora and the alga Halimeda opuntia. Values in bold are significant at $\mathrm{p}<0.05$

\begin{tabular}{|c|c|c|c|c|c|c|}
\hline \multirow{2}{*}{$\begin{array}{c}\text { Source of } \\
\text { variation }\end{array}$} & \multicolumn{3}{|c|}{ — A. millepora- } & \multicolumn{3}{|c|}{$-H$. opuntia } \\
\hline & $\mathrm{df}$ & $F$ & $\mathrm{p}$ & $\mathrm{df}$ & $F$ & $\mathrm{p}$ \\
\hline \multicolumn{7}{|l|}{ Growth rate } \\
\hline $\mathrm{pCO}_{2}$ & 1,29 & 6.78 & 0.032 & 1,8 & 0.60 & 0.460 \\
\hline Light & 1,29 & 64.98 & $<0.001$ & 1,8 & 4.41 & 0.069 \\
\hline $\mathrm{pCO}_{2}$ :light & 1,29 & 0.17 & 0.692 & 1,8 & 0.05 & 0.833 \\
\hline Tank & 8,29 & 2.44 & 0.037 & 8,8 & 1.71 & 0.231 \\
\hline \multicolumn{7}{|c|}{ Net calcification } \\
\hline $\mathrm{pCO}_{2}$ & 1,11 & 4.78 & 0.060 & 1,12 & 3.59 & 0.095 \\
\hline Light & 1,11 & 25.95 & 0.001 & 1,12 & 1.09 & 0.328 \\
\hline $\mathrm{pCO}_{2}$ :light & 1,11 & 1.02 & 0.342 & 1,12 & 0.31 & 0.594 \\
\hline Tank & 8,11 & 1.09 & 0.434 & 8,12 & 2.26 & 0.098 \\
\hline \multicolumn{7}{|c|}{ Light calcification } \\
\hline $\mathrm{pCO}_{2}$ & 1,11 & 0.14 & 0.722 & 1,12 & 0.01 & 0.910 \\
\hline Light & 1,11 & 13.72 & 0.006 & 1,12 & 0.48 & 0.509 \\
\hline $\mathrm{pCO}_{2}$ :light & 1,11 & 0.18 & 0.684 & 1,12 & 0.45 & 0.523 \\
\hline Tank & 8,11 & 1.61 & 0.227 & 8,12 & 2.14 & 0.113 \\
\hline \multicolumn{7}{|c|}{ Dark calcification } \\
\hline $\mathrm{pCO}_{2}$ & 1,11 & 21.45 & 0.002 & 1,12 & 57.53 & $<0.001$ \\
\hline Light & 1,11 & 21.36 & 0.002 & 1,12 & 2.81 & 0.132 \\
\hline $\mathrm{pCO}_{2}$ :light & 1,11 & 2.54 & 0.150 & 1,12 & 0.09 & 0.772 \\
\hline Tank & 8,11 & 0.41 & 0.892 & 8,12 & 4.15 & 0.014 \\
\hline \multicolumn{7}{|c|}{ Gross photosynthesis } \\
\hline $\mathrm{pCO}_{2}$ & 1,12 & 0.00 & 1.000 & 1,11 & 3.51 & 0.098 \\
\hline Light & 1,12 & 208.60 & $<0.001$ & 1,11 & 38.76 & 0.003 \\
\hline $\mathrm{pCO}_{2}$ :light & 1,12 & 0.00 & 1.000 & 1,11 & 0.41 & 0.542 \\
\hline Tank & 8,12 & 1.07 & 0.441 & 8,11 & 1.53 & 0.252 \\
\hline \multicolumn{7}{|c|}{ Net photosynthesis } \\
\hline $\mathrm{pCO}_{2}$ & 1,12 & 0.00 & 1.000 & 1,11 & 3.08 & 0.117 \\
\hline Light & 1,12 & 267.99 & $<0.001$ & 1,11 & 35.85 & $<0.001$ \\
\hline $\mathrm{pCO}_{2}$ :light & 1,12 & 0.21 & 0.661 & 1,11 & 0.47 & 0.512 \\
\hline Tank & 8,12 & 0.77 & 0.636 & 8,11 & 1.40 & 0.297 \\
\hline \multicolumn{7}{|l|}{ Respiration } \\
\hline $\mathrm{pCO}_{2}$ & 1,12 & 0.0 & 0.947 & 1,11 & 2.85 & 0.130 \\
\hline Light & 1,12 & 31.31 & 0.001 & 1,11 & 25.38 & 0.001 \\
\hline $\mathrm{pCO}_{2}$ :light & 1,12 & 0.23 & 0.646 & 1,11 & 0.06 & 0.817 \\
\hline Tank & 8,12 & 4.13 & 0.014 & 8,11 & 3.89 & 0.020 \\
\hline \multicolumn{7}{|c|}{ Chlorophyll a } \\
\hline $\mathrm{pCO}_{2}$ & 1,12 & 0.34 & 0.577 & 1,12 & 1.09 & 0.326 \\
\hline Light & 1,12 & 2.23 & 0.174 & 1,12 & 6.69 & 0.032 \\
\hline $\mathrm{pCO}_{2}$ :light & 1,12 & 0.02 & 0.895 & 1,12 & 1.10 & 0.324 \\
\hline Tank & 8,12 & 3.17 & 0.035 & 8,12 & 1.16 & 0.398 \\
\hline
\end{tabular}

pacted by high $\mathrm{pCO}_{2}$. Low light significantly $(\mathrm{p}<$ 0.0001 ) reduced growth rates of $A$. millepora by $96 \%$ compared to controls, while growth of $H$. opuntia was not significantly reduced (Table $2, \mathrm{p}=0.069$ ).

Net calcification rates (Fig. 1) of Acropora millepora and Halimeda opuntia (measured by alkalinity anomaly) followed similar trends as growth rates measured by buoyant weight (Tables $2 \& 3$ ). The buoyant weight method (integrated over longer 
Table 3. Summary of effects (given as \% change) of treatment variables on response parameters for the coral Acropora millepora and the alga Halimeda opuntia. Decreases $>100 \%$ indicate decalcification. ns: no significant treatment effect ( $\mathrm{p} \geq 0.05)$; measured additive effects: differences of means between the control $\mathrm{pCO}_{2}$ /high light and high $\mathrm{pCO}_{2}$ /low light treatment

\begin{tabular}{|llcccc|}
\hline $\begin{array}{l}\text { Response } \\
\text { parameter }\end{array}$ & Species & $\mathrm{pCO}_{2}$ & Light & \multicolumn{2}{c}{ Additive effect- } \\
& & & & Predicted Measured \\
\hline Growth rate & A. millepora & -48 & -96 & -144 & -114 \\
& H. opuntia & $\mathrm{ns}$ & $\mathrm{ns}$ & $\mathrm{ns}$ & $\mathrm{ns}$ \\
Net calcification & A. millepora & -57 & -99 & -156 & -127 \\
& H. opuntia & $\mathrm{ns}$ & $\mathrm{ns}$ & $\mathrm{ns}$ & $\mathrm{ns}$ \\
Light calcification & A. millepora & $\mathrm{ns}$ & -83 & $\mathrm{~ns}$ & $\mathrm{~ns}$ \\
& H. opuntia & $\mathrm{ns}$ & $\mathrm{ns}$ & $\mathrm{ns}$ & $\mathrm{ns}$ \\
Dark calcification & A. millepora & -155 & -155 & -310 & -204 \\
& H. opuntia & -164 & $\mathrm{~ns}$ & $\mathrm{~ns}$ & $\mathrm{~ns}$ \\
Gross photo- & A. millepora & $\mathrm{ns}$ & -56 & $\mathrm{~ns}$ & $\mathrm{~ns}$ \\
synthesis & H. opuntia & $\mathrm{ns}$ & -57 & $\mathrm{~ns}$ & $\mathrm{~ns}$ \\
Net photo- & A. millepora & $\mathrm{ns}$ & -62 & $\mathrm{~ns}$ & $\mathrm{~ns}$ \\
synthesis & H. opuntia & $\mathrm{ns}$ & -60 & $\mathrm{~ns}$ & $\mathrm{~ns}$ \\
Respiration & A. millepora & $\mathrm{ns}$ & -43 & $\mathrm{~ns}$ & $\mathrm{~ns}$ \\
& H. opuntia & $\mathrm{ns}$ & -48 & $\mathrm{~ns}$ & $\mathrm{~ns}$ \\
Chlorophyll $a$ & A. millepora & $\mathrm{ns}$ & $\mathrm{ns}$ & $\mathrm{ns}$ & $\mathrm{ns}$ \\
content & H. opuntia & $\mathrm{ns}$ & -15 & $\mathrm{~ns}$ & $\mathrm{~ns}$ \\
\hline
\end{tabular}

term) and alkalinity anomaly method (determined in the short term) showed compatible results, and a similar pattern for treatment effects.

Elevated $\mathrm{pCO}_{2}$ had no effect on organisms' calcification in the light (Fig. 1). While low light significantly (Table $2, \mathrm{p}=0.006$ ) reduced light calcification of Acropora millepora by $83 \%$, Halimeda opuntia light calcification was not reduced in low light conditions.

The most distinct effect of elevated $\mathrm{pCO}_{2}$, however, was observed in dark incubations (Fig. 1). Elevated $\mathrm{pCO}_{2}$ significantly reduced calcification of Acropora millepora and Halimeda opuntia (Table 2, p $=0.002$ and $<0.001$, respectively) by 155 and $164 \%$, respectively, with decalcification of their skeletons occurring in high $\mathrm{pCO}_{2}$ conditions. Reduction of calcification by more than $100 \%$ indicates decalcification. Moreover, low light conditions significantly (Table 2, $\mathrm{p}=0.002$ ) reduced dark calcification of $A$. millepora by $155 \%$ compared to controls.

High $\mathrm{pCO}_{2}$ did not show any effect on gross photosynthesis, net photosynthesis or respiration of Acropora millepora or Halimeda opuntia (Fig. 2). However, low light levels significantly reduced gross photosynthesis by 56 and $57 \%$ (both $\mathrm{p}<0.001$ ), net photosynthesis by 62 and $60 \%$ (both $\mathrm{p}<0.001$ ), and respiration by 43 and $48 \%$ (both $\mathrm{p}=0.001$ ) for A. millepora and $H$. opuntia, respectively (Table 2 ).
Chl a content (Fig. 2) of Halimeda opuntia was significantly (Table $2, \mathrm{p}=$ 0.032 ) increased by $15 \%$ in low light conditions compared to controls. Chl a within the coral Acropora millepora was not significantly different among treatments (Table 2).

\section{DISCUSSION}

Negative effects of OA on a range of marine calcifying organisms have been well documented (e.g. Orr et al. 2005, Guinotte \& Fabry 2008, Kleypas \& Yates 2009, Hendriks et al. 2010, Pandolfi et al. 2011, Fabricius et al. 2014). The present study demonstrated that Acropora millepora in particular was negatively affected by elevated $\mathrm{pCO}_{2}$, and that decreased light availability can have an additional impact on both organisms. Although the factors were not synergistic (i.e. higher than the effect of individual stressors added together, see Table 3), additive effects on some response parameters clearly suggest that some corals may better cope with global OA if PAR is not reduced at the same time. With increasing OA, many corals will experience lower growth rates in future. If PAR is reduced at the same time, the inhibitors (elevated $\mathrm{pCO}_{2}$ and reduced PAR) are additive (Dunne 2010) and growth rates of corals impacted by reduced PAR at inshore reefs will be more compromised than those of corals on midshelf reefs. Therefore, by improving water quality the additional stressor of low light availability for inshore corals can be reduced.

In the present study we observed a significant reduction of growth rates for Acropora millepora in high $\mathrm{pCO}_{2}$ conditions after $16 \mathrm{~d}$ in experimental conditions. To date, experiments have revealed mixed responses of coral reef calcifiers towards altered $\mathrm{pCO}_{2}$ conditions, showing decreased growth/calcification in elevated $\mathrm{pCO}_{2}$, or no effect at all (e.g. Ries et al. 2009, Comeau et al. 2013b). Yet, the present study revealed that $A$. millepora belongs to the group which is likely to experience negative impacts under future environmental conditions. Presumably, reduced $\Omega_{\text {ar }}$ is the driving factor of decreased calcification of corals in a high $\mathrm{pCO}_{2}$ environment (Schneider \& Erez 2006, Marubini et al. 2008). Due to a decrease of $\Omega_{\mathrm{ar}}$ in OA conditions, many organisms become im- 

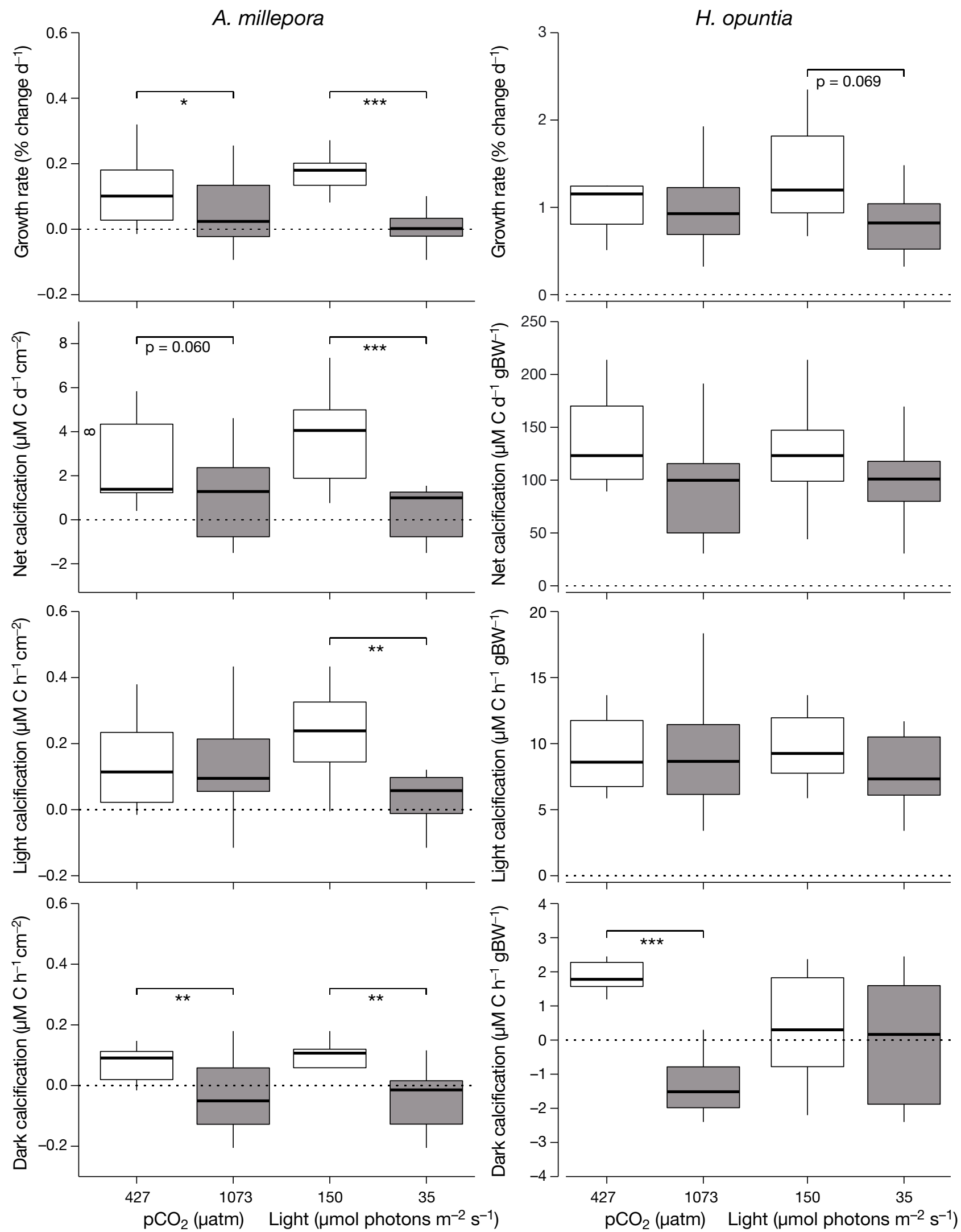

Fig. 1. Growth rates and net, light and dark calcification rates of the coral Acropora millepora and the alga Halimeda opuntia after $16 \mathrm{~d}$ exposure to experimental conditions. Data were pooled across $\mathrm{pCO}_{2}$ and light treatment because there was no significant interaction. Whiskers represent lower and upper extremes. White boxes: control treatments; grey boxes: changed treatments. Dashed lines: zero lines. BW: buoyant weight. Brackets indicate significant differences (or nearly significant; exact p-value given) in ANOVAs. ${ }^{*} \mathrm{p}<0.05,{ }^{* *} \mathrm{p}<0.001,{ }^{* * *} \mathrm{p}<0.0001$ 

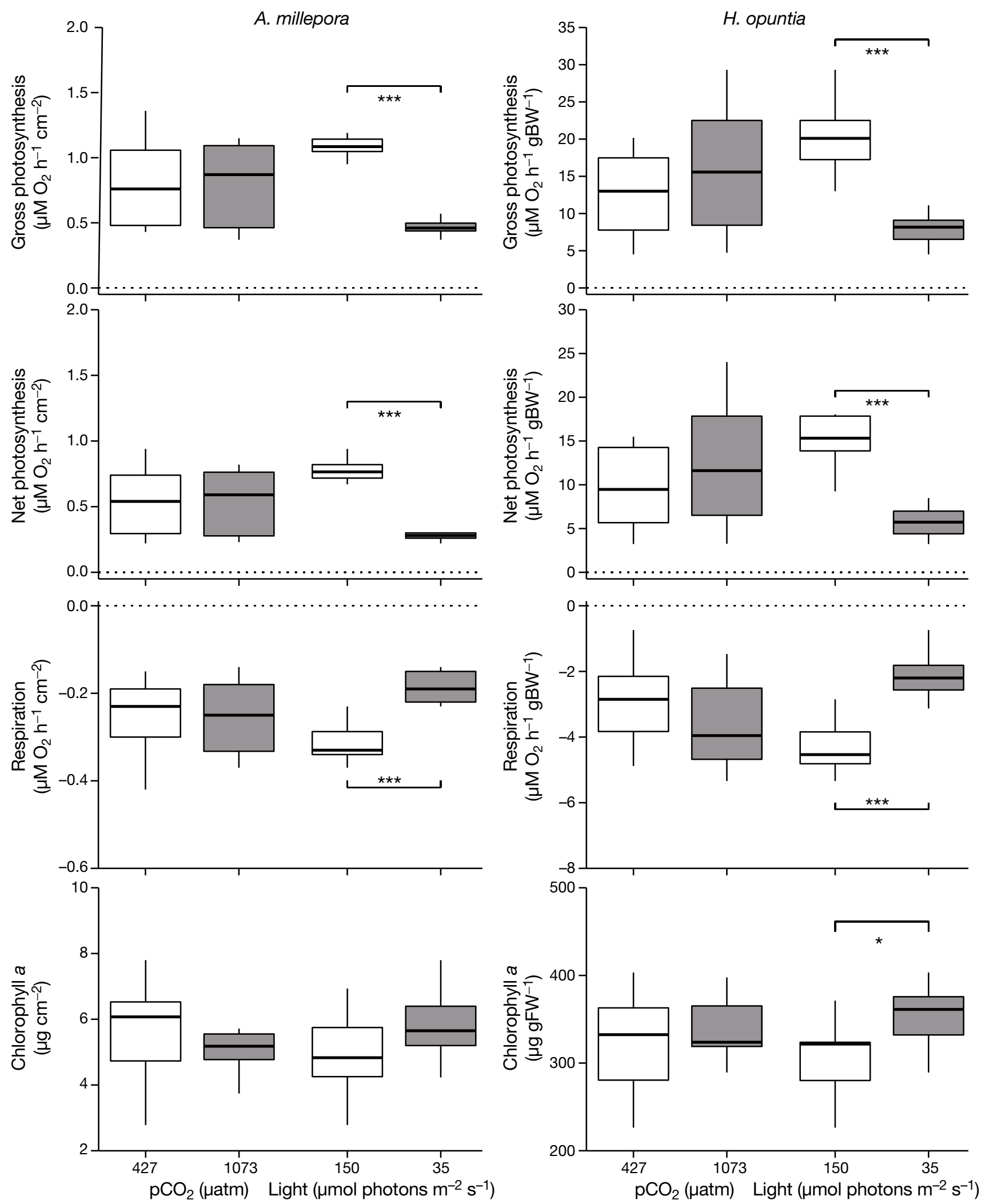

Fig. 2. Gross- and net photosynthesis, and respiration and chlorophyll a content of the coral Acropora millepora and the alga Halimeda opuntia after $16 \mathrm{~d}$ exposure to experimental conditions. Data was pooled across $\mathrm{pCO}_{2}$ and light treatment because there was no significant interaction. Whiskers represent lower and upper extremes. White boxes: control treatments; grey boxes: changed treatments. Dashed lines: zero lines. BW: buoyant weight; FW: fresh weight. Brackets indicate significant differences in ANOVAs. ${ }^{*} \mathrm{p}<0.05,{ }^{* *} \mathrm{p}<0.001,{ }^{* * *} \mathrm{p}<0.0001$ 
paired in building $\mathrm{CaCO}_{3}$ skeletons (Raven et al. 2005, Kleypas \& Langdon 2006, Hoegh-Guldberg et al. 2007). In contrast, Halimeda opuntia showed no significant trend on growth rates in relation to $\Omega_{\mathrm{ar}} /$ $\mathrm{pCO}_{2}$. Some previous studies suggest that Halimeda spp. may be impacted in future OA conditions, showing reduced growth in elevated $\mathrm{pCO}_{2}$ (Ries et al. 2009, Price et al. 2011, Sinutok et al. 2011). However, similar to corals, Halimeda spp. exhibit different growth forms with associated morphological distinctions. Halimeda spp. occur as heavily calcified and less calcified species, sand-dwellers and rockanchored species as well as species with different sizes and shapes of phylloids. Halimeda spp. with smaller phylloids have a higher surface to volume ratio than with larger phylloids and hence have a higher exposure to their physical environment. As shown by Comeau et al. (2013b), H. macroloba showed no impact of increased $\mathrm{pCO}_{2}$ on calcification, but $H$. minima showed reduced calcification in elevated $\mathrm{pCO}_{2}$. However, different outcomes may also arise from different methodologies implemented, such as flow conditions, nutrient availability, size of organisms, level of $\mathrm{pCO}_{2}$ condition implemented, or combinations of different stressors (e.g. OA and OW). The impact of elevated $\mathrm{pCO}_{2}$ on growth of $H$. opuntia in Price et al. (2011) compared to the lack of response to elevated $\mathrm{pCO}_{2}$ in the present study is unclear. We propose that different results mainly arose due to different methodologies being implemented. The present study used flow-through conditions with a constant supply of fresh filtered seawater and associated nutrients, while in Price et al. (2011), 0.71 tanks were utilized with water exchange every $48 \mathrm{~h}$, not accounting for nutrient depletion. Moreover, daily light sums of control light in the present study were considerably higher and closer to natural light conditions than reduced natural light regimes in Price et al. (2011), where light maxima at midday averaged $150 \mu \mathrm{mol}$ photons $\mathrm{m}^{-2} \mathrm{~s}^{-1}$. In the present study we chose a $\mathrm{pCO}_{2}$ level which is likely to be reached by the year 2100 under projections between the RCP 6.0 and RCP 8.5 scenario (Moss et al. 2010), the experimental set-up provided flow-through conditions with continuous supply of nutrients and light regimes naturally found on mid-shelf and inshore locations of the GBR at $5 \mathrm{~m}$ below LAT. One explanation for why $H$. opuntia is capable of growth in a high $\mathrm{pCO}_{2}$ environment while $A$. millepora is not may be that calcification rates in Halimeda spp. are generally higher than in corals (when both standardized to either surface area or buoyant weight). For H. opuntia, daytime calcification rates were approximately one order of magni- tude higher than dissolution rates in the dark under elevated $\mathrm{pCO}_{2}$ conditions. Thus, even when some dissolution is taking place in the dark, higher light calcification rates sum up to positive net calcification rates. In contrast, for A. millepora, dark dissolution and light calcification rate were in a similar range, indicating net dissolution if impacts of future OA and low light conditions become additive (Table 3).

Notably, light calcification rates of both organisms, determined using the alkalinity anomaly technique, were unaffected by increased $\mathrm{pCO}_{2}$. To our knowledge, this is the first study to show that calcification of Acropora millepora and Halimeda opuntia in elevated $\mathrm{pCO}_{2}$ is not impacted in the light and supports the assumption that in the light, photosynthetic activity can counteract negative impacts of OA by increasing intracellular, surface and boundary-layer $\mathrm{pH}$. By utilizing $\mathrm{CO}_{2}$, photosynthesis increases $\mathrm{pH}$ and $\Omega_{\text {ar }}$ (de Beer et al. 2000, de Beer \& Larkum 2001, Glas et al. 2012). As shown by Al-Horani et al. (2003), pH increases under the calcioblastic layer of corals in light, which elevated the super saturation of $\Omega_{\mathrm{ar}}$ from 3.2 up to 25, facilitating deposition of $\mathrm{CaCO}_{3}$ (Goreau 1959, Al-Horani et al. 2003).

However, the present study also suggested that for dark calcification rates, the opposite effect is the case. During respiration in the dark, additional $\mathrm{CO}_{2}$ further reduces $\mathrm{pH}$ and $\Omega_{\mathrm{ar}}$ (already lowered by OA) and impedes deposition of $\mathrm{CaCO}_{3}$. Hence, in the absence of light, both organisms were strongly negatively impacted by high $\mathrm{pCO}_{2}$ conditions, leading to dissolution of their skeleton. In contrast, under present-day conditions, both organisms can calcify in the dark (i.e. in the absence of photosynthesis). This observation is in agreement with a previous study, showing decalcification of Acropora eurystoma in high $\mathrm{pCO}_{2}$ and darkness, while $\mathrm{CaCO}_{3}$ was still deposited under control conditions or in high $\mathrm{pCO}_{2}$ in the light (Schneider \& Erez 2006). Previous studies have also shown that reef communities can change the diurnal local seawater carbonate chemistry by photosynthesis, respiration, calcification and dissolution, and that $\mathrm{CaCO}_{3}$ dissolution is primarily taking place in the dark (Chisholm 2000, Langdon \& Atkinson 2005, Kleypas et al. 2011, Anthony et al. 2013). While respiration is taking place in the dark, additional $\mathrm{CO}_{2}$ is added to the carbonate system and already lowered $\mathrm{pH}$ levels from $\mathrm{OA}$ are further reduced, leading to an additional reduction of $\Omega_{\mathrm{ar}}$ as already provoked by OA. Consequently, A. millepora and Halimeda opuntia were incapable of depositing $\mathrm{CaCO}_{3}$ in the dark and even experienced dissolution of their skeletons under these conditions. 
Considering the negative impacts of OA in darkness, we demonstrated that low light conditions may likewise result in additional negative implications on organisms, once PAR is reduced below a level at which photosynthesis cannot buffer reduced $\mathrm{pH}$ by OA. Presumably, this threshold level is below $35 \mu \mathrm{mol}$ photons $\mathrm{m}^{-2} \mathrm{~s}^{-1}$ as tested in the present study. As shown in the present study by measurements in the light, OA showed no impact on calcification rates of either organism. Thus, the availability of sufficient light, associated with photosynthetic activity and apparent buffer capacity, mitigated negative effects of OA in light incubations. However, turbidity decreases PAR and therefore reduces the capability of the organisms' photosynthesis to buffer the negative impacts of OA, even during the day. As shown by our $\mathrm{O}_{2}$ flux measurements, low light regimes significantly decreased gross and net photosynthesis in both organisms. This enhances negative impacts of OA during the day, especially at inshore reefs, where riverine runoff leads to reduced PAR (Devlin \& Schaffelke 2009). Light data from mid-shelf and inshore GBR reefs at $5 \mathrm{~m}$ below LAT show that light availability can be extremely reduced at inshore reefs, considerably impacting organisms' photosynthetic capacities. Moreover, reduced photosynthetic activity of organisms experiencing reduced light availability may also change DIC/carbonate chemistry on inshore reefs compared to mid-shelf locations. Under low light conditions, mean growth rates of both the coral and algae were reduced compared to higher light. Light-enhanced photosynthesis and calcification of coral and algae is a well-documented phenomenon (Goreau 1959, Chalker \& Taylor 1975, Chalker 1981, de Beer et al. 2000, de Beer \& Larkum 2001). With increasing OA and the additive negative effects of low light on coral growth, as demonstrated in the present study, the mechanism of light-enhanced calcification may gain in importance. Moreover, under lower light conditions, when photosynthetic activity is reduced, organisms obtain less energy supply, thus reducing the scope for growth.

Photosynthesis of algae and coral can be limited by dissolved inorganic carbon (DIC) availability (Borowitzka \& Larkum 1976, de Beer \& Larkum 2001, Marubini et al. 2008, Crawley et al. 2010, Chauvin et al. 2011). Carbonic anhydrase can utilize elevated bicarbonate availability to increase the $\mathrm{CO}_{2}$ pool available for photosynthetic activity. Thus we assumed that photosynthesis could be enhanced under higher $\mathrm{pCO}_{2}$. However, photosynthesis of the organisms investigated here could not benefit from increased DIC concentrations. This may have 2 different rea- sons: (1) the organisms were not DIC-limited in experimental control conditions; (2) under present light conditions, photosynthesis/calcification of organisms was not saturated and hence there was no detectable benefit from increased DIC availability. Studies conducted by Marubini et al. (2008) and Crawley et al. (2010) indicating DIC limitation both utilized higher light intensities than the present study ( 300 and $\sim 1000 \mu \mathrm{mol}$ photons $\mathrm{m}^{-2} \mathrm{~s}^{-1}$, respectively). This suggests that under present experimental conditions (i.e. present light intensities) calcification and photosynthesis were not DIC-limited.

Moreover, we showed that in decreased PAR, Halimeda opuntia increased its tissue chl a content in order to compensate for less light availability, while the coral was not able to do so over the period of the experiment. By adjusting its chl a content, the alga might acclimate to reduced light availability in the short term, and increase its photosynthetic capacity in low light. Increased productivity changes the carbonate chemistry to the advantage of the algae by facilitating deposition of $\mathrm{CaCO}_{3}$. In contrast, Acropora millepora did not have this advantage because it could not increase chl a over the $16 \mathrm{~d}$ experimental period and thus may not be able to acclimate in the short term to decreased light availability. As shown by previous studies, corals alter their chl a content by having either a higher number of zooxanthellae per unit area, or by an increase of chl a content in the zooxanthellae (Coles \& Jokiel 1978, Chauvin et al. 2011). Field data suggest that A. millepora show increased pigmentation with decreasing water clarity from mid-shelf to inshore (Fabricius 2006). However, this might also be a response towards a more chronic exposure to low light conditions and other water quality parameters (i.e. increased nutrient availability at inshore reefs). Therefore, the algae may show more immediate responses towards changing light regimes and thus have an advantage in acclimation compared to the coral.

Acropora millepora and Halimeda opuntia did not exhibit significant interactive effects on response parameters measured, which is an indication that effects were not synergistic (Dunne 2010). Similarly, Comeau et al. (2013a, 2014) found no interactive effects of $\mathrm{OA}$ and irradiance on calcification rates of Porites rus and Acropora pulchra, respectively, after 3 wk exposure to experimental conditions. In contrast, a study on Pocillopora damicornis recruits presented interactive effects of OA and light after $5 \mathrm{~d}$ of experimentation (Dufault et al. 2013). However, the responses were non-linear and impacts of OA on calcification rates were only found at intermediate light 
intensities $\left(70 \mu \mathrm{mol}\right.$ photons $\left.\mathrm{m}^{-2} \mathrm{~s}^{-1}\right)$ and not at lower or higher light levels $(31,41,122$ and $226 \mu \mathrm{mol}$ photons $\mathrm{m}^{-2} \mathrm{~s}^{-1}$ ). Moreover, a study on Acropora horrida and Porites cylindrica showed impacts of OA on calcification that were greatest in light calcification of corals grown in lower light conditions $(100 \mu \mathrm{mol}$ photons $\mathrm{m}^{-2} \mathrm{~s}^{-1}$ ) compared to corals grown in higher light $\left(400 \mu \mathrm{mol}\right.$ photons $\mathrm{m}^{-2} \mathrm{~s}^{-1}$ ) after $5 \mathrm{wk}$ (Suggett et al. 2013). This is unexpected and in contrast to the present study, where the impact of OA on calcification was not significant in the light, but was strong in the dark. In the present study A. millepora did not show interactive effects of OA and light; however, there were additive effects of both stressors. We detected reduced growth rates $(-48 \%)$ when exposed to high $\mathrm{pCO}_{2}$ conditions and also reduced growth rates when exposed to low light regimes $(-96 \%)$, which resulted in a predicted additive growth rate of $-144 \%$ (which is similar to the measured $-114 \%$ growth rate) (Table 3). This may have an ecological implication for corals inhabiting inshore reefs susceptible to land-runoff and thus decreased light availability. Turbidity changes the attenuation of light penetrating the water column, decreasing PAR with increasing depth more rapidly than in clear water conditions. This, in turn, may lead to a stronger depth limitation for corals and thus to potential habitat decline in future OA conditions, because they gain less light with lower water depth compared to clear water habitats.

\section{CONCLUSIONS}

In the present experiment, we confirmed that the marine calcifiers investigated are negatively impacted by ocean acidification, with Acropora millepora showing more negative impacts than Halimeda opuntia. As long as sufficient light is available during the day, photosynthesis aids organisms to counteract negative impacts of OA. However, if there is not sufficient light available (e.g. due to high turbidity), there may be impacts of OA on calcification also during the day. Thus, low light conditions inshore remove this advantage from photosynthesizing organisms. As suggested by the dark incubations, respiration potentially aggravates the impacts of $\mathrm{OA}$ on the organisms, leading to dissolution of their skeleton. This highlights the importance of considering lightdependent impacts of OA on photosynthesizing calcifiers. Moreover, we showed that decreased light availability is an additive stressor with OA, particularly for the coral A. millepora, because the coral exhibits reduced calcification in OA conditions as well as in low light conditions. $H$. opuntia, on the other hand, grows marginally less in low light, but was not negatively impacted by $\mathrm{OA}$ in its overall growth. Consequently, the combination of OA and low light conditions may contribute to a changing coral reef ecosystem with even less hard corals as framework builders and more macroalgae on inshore reefs of the future. Potential acclimatization to environmental stressors in the long term could lead to different responses of organisms. Therefore, further investigations are needed to test the effects of OA in combination with light availability on coral reef organisms. Management of coastal runoff could also play an important role, as by improving water clarity on inshore reefs, the additional stressor of low light availability for corals would be reduced.

Acknowledgements. The authors thank the SeaSim team at AIMS for providing the coral nubbins and their general assistance. We thank Michelle Liddy for her assistance in the field and laboratory. Many thanks for general assistance from Florita Flores. We acknowledge the National Environmental Research Program, which provided the stipend for Nikolas Vogel. This study was conducted with the support of funding from the Australian Government's National Environmental Research Program and an Australian Research Council Discovery Grant.

\section{LITERATURE CITED}

Al-Horani FA, Al-Moghrabi SM, de Beer D (2003) The mechanism of calcification and its relation to photosynthesis and respiration in the scleractinian coral Galaxea fascicularis. Mar Biol 142:419-426

> Anthony KRN, Diaz-Pulido G, Verlinden N, Tilbrook B, Andersson AJ (2013) Benthic buffers and boosters of ocean acidification on coral reefs. Biogeosciences 10: 4897-4909

Bell PRF (1992) Eutrophication and coral reefs - some examples in the Great Barrier Reef lagoon. Water Res 26: 553-568

Bindoff NL, Willebrand J, Artale V, Cazenave A and others (2007) Observations: oceanic climate change and sea level. In: Solomon S, Qin D, Manning M, Chen Z and others (eds) Climate change 2007: the physical science basis contribution of Working Group I to the 4th assessment report of the Intergovernmental Panel on Climate Change. Cambridge University Press, Cambridge, p 385-432

> Borowitzka MA, Larkum AWD (1976) Calcification in the green alga Halimeda III. The sources of inorganic carbon for photosynthesis and calcification and a model of the mechanism of calcification. J Exp Bot 27:879-893

> Chalker BE (1981) Simulating light-saturation curves for photosynthesis and calcification by reef-building corals. Mar Biol 63:135-141

> Chalker BE, Taylor DL (1975) Light-enhanced calcification, and the role of oxidative phosphorylation in calcification of the coral Acropora cervicornis. Proc R Soc Lond B Biol Sci 190:323-331 
Chauvin A, Denis V, Cuet P (2011) Is the response of coral calcification to seawater acidification related to nutrient loading? Coral Reefs 30:911-923

Chisholm JRM (2000) Calcification by crustose coralline algae on the northern Great Barrier Reef, Australia. Limnol Oceanogr 45:1476-1484

> Chisholm JRM, Gattuso JP (1991) Validation of the alkalinity anomaly technique for investigating calcification and photosynthesis in coral-reef communities. Limnol Oceanogr 36:1232-1239

Coles S, Jokiel P (1978) Synergistic effects of temperature, salinity and light on the hermatypic coral Montipora verrucosa. Mar Biol 49:187-195

> Comeau S, Carpenter RC, Edmunds PJ (2013a) Effects of feeding and light intensity on the response of the coral Porites rus to ocean acidification. Mar Biol 160: 1127-1134

> Comeau S, Edmunds PJ, Spindel NB, Carpenter RC (2013b) The responses of eight coral reef calcifiers to increasing partial pressure of $\mathrm{CO}_{2}$ do not exhibit a tipping point. Limnol Oceanogr 58:388-398

Comeau S, Carpenter RC, Edmunds PJ (2014) Effects of irradiance on the response of the coral Acropora pulchra and

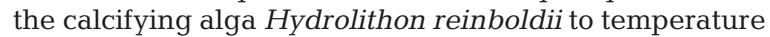
elevation and ocean acidification. J Exp Mar Biol Ecol 453:28-35

> Crawley A, Kline DI, Dunn S, Anthony K, Dove S (2010) The effect of ocean acidification on symbiont photorespiration and productivity in Acropora formosa. Global Change Biol 16:851-863

$>$ De'ath G, Fabricius KE (2010) Water quality as a regional driver of coral biodiversity and macroalgae on the Great Barrier Reef. Ecol Appl 20:840-850

$>$ de Beer D, Larkum AWD (2001) Photosynthesis and calcification in the calcifying algae Halimeda discoidea studied with microsensors. Plant Cell Environ 24:1209-1217

de Beer D, Kühl M, Stambler N, Vaki L (2000) A microsensor study of light enhanced $\mathrm{Ca}^{2+}$ uptake and photosynthesis in the reef-building hermatypic coral Favia sp. Mar Ecol Prog Ser 194:75-85

> Devlin M, Schaffelke B (2009) Spatial extent of riverine flood plumes and exposure of marine ecosystems in the Tully coastal region, Great Barrier Reef. Mar Freshw Res 60: 1109-1122

Dlugokencky E, Tans P (2014) Trends in atmospheric carbon dioxide: recent global $\mathrm{CO}_{2}$. www.esrl.noaa.gov/gmd/ccgg/ trends/

> Dufault AM, Ninokawa A, Bramanti L, Cumbo VR, Fan TY, Edmunds PJ (2013) The role of light in mediating the effects of ocean acidification on coral calcification. J Exp Biol 216:1570-1577

> Dunne RP (2010) Synergy or antagonism-interactions between stressors on coral reefs. Coral Reefs 29:145-152

$>$ Fabricius KE (2005) Effects of terrestrial runoff on the ecology of corals and coral reefs: review and synthesis. Mar Pollut Bull 50:125-146

Fabricius KE (2006) Effects of irradiance, flow, and colony pigmentation on the temperature microenvironment around corals: implications for coral bleaching? Limnol Oceanogr 51:30-37

Fabricius KE (2011) Factors determining the resilience of coral reefs to eutrophication: a review and conceptual model. In: Dubinsky Z, Stambler N (eds) Coral reefs: an ecosystem in transition. Springer, New York, NY, p 493-505

Fabricius KE, De'ath G, McCook L, Turak E, Williams DE (2005) Changes in algal, coral and fish assemblages along water quality gradients on the inshore Great Barrier Reef. Mar Pollut Bull 51:384-398

Fabricius KE, Langdon C, Uthicke S, Humphrey C and others (2011) Losers and winners in coral reefs acclimatized to elevated carbon dioxide concentrations. Nat Clim Change 1:165-169

Fabricius KE, De'ath G, Noonan S, Uthicke S (2014) Ecological effects of ocean acidification and habitat complexity on reef-associated macroinvertebrate communities. Proc R Soc Lond B Biol Sci 281:20132479

Freile D, Milliman J, Hillis L (1995) Leeward bank margin Halimeda meadows and draperies and their sedimentary importance on the western Great Bahama Bank slope. Coral Reefs 14:27-33

Fukunaga A (2008) Invertebrate community associated with the macroalga Halimeda kanaloana meadow in Maui, Hawaii. Int Rev Hydrobiol 93:328-341

Gao K, Zheng Y (2010) Combined effects of ocean acidification and solar UV radiation on photosynthesis, growth, pigmentation and calcification of the coralline alga Corallina sessilis (Rhodophyta). Global Change Biol 16: 2388-2398

Gattuso JP, Frankignoulle M, Bourge I, Romaine S, Buddemeier RW (1998) Effect of calcium carbonate saturation of seawater on coral calcification. Global Planet Change 18:37-46

Glas MS, Fabricius KE, de Beer D, Uthicke S (2012) The $\mathrm{O}_{2}$ $\mathrm{pH}$ and $\mathrm{Ca}^{2+}$ microenvironment of benthic foraminifera in a high $\mathrm{CO}_{2}$ world. PLoS ONE 7:e50010

Golubik S, Krumbein W, Schneider K (1979) The carbon cycle. In: Trudinger PA, Swaine DJ (eds) Biogeochemical cycling of mineral-forming elements. Elsevier, Amsterdam, p 29-45

> Goreau TF (1959) The physiology of skeleton formation in corals. I. A method for measuring the rate of calcium deposition by corals under different conditions. Biol Bull 116: 59-75

Guinotte JM, Fabry VJ (2008) Ocean acidification and its potential effects on marine ecosystems. Ann NY Acad Sci 1134:320-342

> Hendriks IE, Duarte CM, Álvarez M (2010) Vulnerability of marine biodiversity to ocean acidification: a meta-analysis. Estuar Coast Shelf Sci 86:157-164

Hintze J (2007) NCSS. NCSS, LCC, Kaysville, UT

> Hoegh-Guldberg O, Mumby PJ, Hooten AJ, Steneck RS and others (2007) Coral reefs under rapid climate change and ocean acidification. Science 318:1737-1742

Kendall JJ Jr, Powell EN, Connor SJ, Bright TJ (1983) The effects of drilling fluids (muds) and turbidity on the growth and metabolic state of the coral Acropora cervicornis, with comments on methods of normalization for coral data. Bull Mar Sci 33:336-352

Kendall JJ Jr, Powell EN, Connor SJ, Bright TJ, Zastrow CE (1985) Effects of turbidity on calcification rate, protein concentration and the free amino acid pool of the coral Acropora cervicornis. Mar Biol 87:33-46

Kleypas JA, Langdon C (2006) Coral reefs and changing seawater carbonate chemistry. In: Phinney JT, HoeghGuldberg O, Kleypas J, Skirving W, Strong A (eds) Coastal and estuarine studies: coral reefs and climate change science and management. American Geophysical Union, Washington, DC, p 73-110

Kleypas JA, Yates KK (2009) Coral reefs and ocean acidification. Oceanography 22:108-117

Kleypas JA, Anthony K, Gattuso JP (2011) Coral reefs modify their seawater carbon chemistry - case study from a barrier reef (Moorea, French Polynesia). Global Change Biol 17:3667-3678 
Langdon C, Atkinson MJ (2005) Effect of elevated $\mathrm{pCO}_{2}$ on photosynthesis and calcification of corals and interactions with seasonal change in temperature/irradiance and nutrient enrichment. J Geophys Res 110:C09S07

> Langdon C, Takahashi T, Sweeney C, Chipman D and others (2000) Effect of calcium carbonate saturation state on the calcification rate of an experimental coral reef. Global Biogeochem Cycles 14:639-654

> Lueker TJ, Dickson AG, Keeling CD (2000) Ocean $\mathrm{pCO}_{2}$ calculated from dissolved inorganic carbon, alkalinity, and equations for $\mathrm{K} 1$ and $\mathrm{K} 2$ : validation based on laboratory measurements of $\mathrm{CO}_{2}$ in gas and seawater at equilibrium. Mar Chem 70:105-119

> Marubini F, Barnett H, Langdon C, Atkinson MJ (2001) Dependence of calcification on light and carbonate ion concentration for the hermatypic coral Porites compressa. Mar Ecol Prog Ser 220:153-162

Marubini F, Ferrier-Pages C, Furla P, Allemand D (2008) Coral calcification responds to seawater acidification: a working hypothesis towards a physiological mechanism. Coral Reefs 27:491-499

Mass T, Einbinder S, Brokovich E, Shashar N, Vago R, Erez J, Dubinsky Z (2007) Photoacclimation of Stylophora pistillata to light extremes: metabolism and calcification. Mar Ecol Prog Ser 334:93-102

McCulloch M, Fallon S, Wyndham T, Hendy E, Lough J, Barnes D (2003) Coral record of increased sediment flux to the inner Great Barrier Reef since European settlement. Nature 421:727-730

Moss RH, Edmonds JA, Hibbard KA, Manning MR and others (2010) The next generation of scenarios for climate change research and assessment. Nature 463:747-756

Negri AP, Flores F, Roethig T, Uthicke S (2011) Herbicides increase the vulnerability of corals to rising sea surface temperature. Limnol Oceanogr 56:471-485

Nusch EA (1980) Comparison of different methods for chlorophyll and phaeopigment determination. Arch Hydrobiol Beih 14:14-36

> Orr JC, Fabry VJ, Aumont O, Bopp L and others (2005) Anthropogenic ocean acidification over the twenty-first century and its impact on calcifying organisms. Nature 437:681-686

Pandolfi JM, Connolly SR, Marshall DJ, Cohen AL (2011) Projecting coral reef futures under global warming and ocean acidification. Science 333:418-422

Price NN, Hamilton SL, Tootell JS, Smith JE (2011) Speciesspecific consequences of ocean acidification for the calcareous tropical green algae Halimeda. Mar Ecol Prog Ser 440:67-78

R Development Core Team (2014) R: a language and environment for statistical computing. R Foundation for Statistical Computing, Vienna

Raven J, Caldeira K, Elderfield H, Hoegh-Guldberg $\mathrm{O}$ and others (2005) Ocean acidification due to increasing atmospheric carbon dioxide. The Royal Society, London

Rees SA, Opdyke BN, Wilson PA, Henstock TJ (2007) Significance of Halimeda bioherms to the global carbonate budget based on a geological sediment budget for the Northern Great Barrier Reef, Australia. Coral Reefs 26: $177-188$

> Ries JB, Cohen AL, McCorkle DC (2009) Marine calcifiers

Editorial responsibility: Brian Helmuth,

Nahant, Massachusetts, USA exhibit mixed responses to $\mathrm{CO}_{2}$-induced ocean acidification. Geology 37:1131-1134

Robbins LL, Hansen ME, Kleypas JA, Meylan SC (2010) CO2calc-A user-friendly seawater carbon calculator for Windows, Max OS X, and iOS (iPhone). Geological Survey Open-File Report 2010-1280:17

Roff G, Clark TR, Reymond CE, Zhao J and others (2013) Palaeoecological evidence of a historical collapse of corals at Pelorus Island, inshore Great Barrier Reef, following European settlement. Proc R Soc Lond B Biol Sci 280:20122100

Schaffelke B, Mellors J, Duke NC (2005) Water quality in the Great Barrier Reef region: responses of mangrove, seagrass and macroalgal communities. Mar Pollut Bull 51: 279-296

> Schmidt C, Heinz P, Kucera M, Uthicke S (2011) Temperature-induced stress leads to bleaching in larger benthic foraminifera hosting endosymbiotic diatoms. Limnol Oceanogr 56:1587-1602

Schneider K, Erez J (2006) The effect of carbonate chemistry on calcification and photosynthesis in the hermatypic coral Acropora eurystoma. Limnol Oceanogr 51: 1284-1293

Sinutok S, Hill R, Doblin MA, Wuhrer R, Ralph PJ (2011) Warmer more acidic conditions cause decreased productivity and calcification in subtropical coral reef sedimentdwelling calcifiers. Limnol Oceanogr 56:1200-1212

Suggett DJ, Dong LF, Lawson T, Lawrenz E, Torres L, Smith DJ (2013) Light availability determines susceptibility of reef building corals to ocean acidification. Coral Reefs 32:327-337

Uthicke S, Altenrath C (2010) Water column nutrients control growth and $\mathrm{C}: \mathrm{N}$ ratios of symbiont-bearing benthic foraminifera on the Great Barrier Reef, Australia. Limnol Oceanogr 55:1681-1696

Uthicke S, Fabricius KE (2012) Productivity gains do not compensate for reduced calcification under near future ocean acidification in the photosynthetic benthic foraminifer species Marginopora vertebralis. Global Change Biol 18:2781-2791

Uthicke S, Vogel N, Doyle J, Schmidt C, Humphrey C (2011) Interactive effects of climate change and eutrophication on the dinoflagellate-bearing benthic foraminifer Marginopora vertebralis. Coral Reefs 31:401-414

> Veal C, Carmi M, Fine M, Hoegh-Guldberg O (2010) Increasing the accuracy of surface area estimation using single wax dipping of coral fragments. Coral Reefs 29: 893-897

> Vogel N, Uthicke S (2012) Calcification and photobiology in symbiont-bearing benthic foraminifera and responses to a high $\mathrm{CO}_{2}$ environment. J Exp Mar Biol Ecol 424425:15-24

Wainwright SA (1963) Skeletal organization in the coral, Pocillopora damicornis. Q J Microsc Sci 3:169-183

Wefer G (1980) Carbonate production by algae Halimeda, Penicillus and Padina. Nature 285:323-324

Wooldridge S, Brodie J, Furnas M (2006) Exposure of innershelf reefs to nutrient enriched runoff entering the Great Barrier Reef lagoon: post-European changes and the design of water quality targets. Mar Pollut Bull 52: 1467-1479

Submitted: January 17, 2014; Accepted: October 20, 2014

Proofs received from author(s): January 21, 2015 